\title{
Penerapan Arbitrase Online dalam Penyelesaian Sengketa Transaksi E-Commerce
}

\author{
Abdul Halim Barkatullah \\ Fakultas Hukum Univerrsitas Lambung Mangkurat Banjarmasin \\ Jl.Jalan Brigjend Hasan Basry Banjarmasin 70123 \\ dr.halim_barkatullah@yahoo.co.id
}

\begin{abstract}
This research focuses on method of dispute resolution using online arbitration as online dispute resolution. This research character is analytical descriptive. Analysis method used in this research is qualitative method. The result of this research shows: First, online arbitration as one of the method of dispute resolution using online dispute resolution considered by e-commerce business actors as the best solution in resolving dispute in cyber world; Second, online arbitration in the practice faces juridical obstacle in some matters as follow: (1) agreement to perform arbitration; (2) choice of arbiter (3) fulfillment of fundamental procedures; (4) character and execution of arbitration binding decision.
\end{abstract}

Key words: Online arbitration, dispute, and e-commerce.

\begin{abstract}
Abstrak
Penelitian ini difokuskan pada, cara penyelesaian sengketa yang menggunakan arbitrase online sebagai online dispute resolution. Sifat penelitian ini adalah deskriptif analitis. Analisis yang digunakan dalam penelitian ini adalah metode kualitatif. Hasil dari penelitian ini menunjukkan: Pertama, arbitrase online sebagai salah satu cara penyelesaian sengketa dengan menggunakan online dispute resolution dianggap oleh para pelaku bisnis e-commerce sebagai solusi terbaik dalam menyelesaikan masalah sengketa di dunia maya; Kedua, arbitrase online dalam pelaksanaannya menghadapi kendala yuridis, dalam hal: (1) kontrak untuk melakukan arbitrase; (2) pemilihan arbiter; (3) pemenuhan prinsip prosedur dasar; (4) sifat dan pelaksanaan keputusan yang mengikat dari arbitrase.
\end{abstract}

Kata kunci : Arbitrase on line, sengketa, dan e-commerce 


\section{Pendahuluan}

Sengketa sebagai suatu keadaan di mana pihak-pihak yang melakukan upaya perniagaan mempunyai masalah, yaitu menghendaki pihak lain untuk berbuat atau tidak berbuat sesuatu tetapi pihak lainnya menolak atau tidak berlaku demikian. ${ }^{1}$ Sengketa dapat juga dimaksudkan sebagai adanya ketidakserasian antara pribadi atau kelompok yang mengadakan hubungan karena hak salah satu pihak terganggu atau dilanggar. ${ }^{2}$

Apabila timbul suatu perselisihan yang menyangkut suatu transaksi e-commerce di mana para pihak berkedudukan di Indonesia dan transaksi itu berlangsung di Indonesia, walaupun di antara mereka tidak membuat kontrak mengenai pilihan hukum, maka hal itu mudah bagi hakim untuk menentukan atau para pihak melakukan kesepakatan di kemudian hari, setelah timbulnya perselisihan antara mereka, agar perselisihan itu diselesaikan menurut hukum Indonesia. ${ }^{3}$

Apabila transaksi e-commerce tersebut berlangsung di antara para pihak khususnya perorangan, yang merupakan penduduk dua negara yang berbeda, maka akan timbul masalah penerapan hukum negara tergugat, atau berdasarkan hukum negara penggugat, atau apakah seyogyanya didasarkan kepada negara pelaku usaha, atau apakah didasarkan hukum negara dari pembeli.

Apabila yang diberlakukan adalah hukum dari negara di mana perbuatan itu dilakukan, akan sulit sekali menentukan di negara mana perbuatan itu dilakukan. Apakah perbuatan itu dilakukan di Indonesia atau Amerika Serikat. Mengingat transaksi itu terjadi di dunia maya (virtual world atau cyberspace) yang tidak mengenal batas negara, maka sulit menentukan di negara mana peristiwa hukum itu terjadi. Karena transaksi tersebut di dunia maya, maka transaksi itu tidak dapat dikatakan terjadi di Amerika Serikat atau terjadi di Indonesia. ${ }^{4}$

Demikian pula mengenai pilihan pengadilan atau suatu badan arbitrase yang akan memeriksa sengketa tersebut, apabila para pihak tidak menentukan pilihan

\footnotetext{
${ }^{1}$ Komar Kartaatmadja, Beberapa Masalab Dalam Penerapan ADR Di Indonesia, Dalam Prospek dan Pelaksanaan Arbitrase di Indonesia, PT Citra Aditya Bakti, Bandung, 2001, hlm. 37.

${ }^{2}$ Soeryono Soekanto, Mengenai Antropologi Hukum, Alumni, Bandung, 2002, hlm. 26.

${ }^{3}$ Sutan Remy Sjahdeini, "E-Commerce Tinjauan dari Perspektif Hukum". Jurnal Hukum Bisnis, diterbitkan oleh Yayasan Pengembangan Hukum Bisnis. Vol.12, 2001, Jakarta, hlm. 24.

${ }^{4}$ Mariam Darus Badrulzaman, et.al., Kompilasi Hukum Perikatan, PT. Citra Aditya Bakti, Bandung, 2003, hlm. 303.
} 
pengadilan atau suatu badan arbitrase terlebih dahulu, maka akan menjadi masalah jika timbul sengketa. ${ }^{5}$

Arbitrase Online sebagai salah satu cara penyelesaian sengketa dengan menggunakan Online Dispute Resolution (ODR), yang merupakan perkembangan dari cara penyelesaian sengketa non litigasi yang ada di dunia nyata. Cara penyelesaian sengketa dengan menggunakan ODR dianggap oleh para pelaku bisnis di dunia maya (e-commerce), sebagai solusi terbaik dalam menyelesaikan masalah sengketa di dunia maya, namun banyak kendala hukum dalam penerapan sistem penyelesaian sengketa ini di Indonesia.

\section{Rumuan Masalah}

Pertama, bagaimanakah cara penyelesaian sengketa yang menggunakan arbitrase online sebagai ODR? Kedua, apakah arbitrase online dalam penyelesaian sengketa bisnis e-commerce sudah sesuai dengan cara penyelesaian sengketa di Indonesia?

\section{Tujuan Penelitian}

Pertama, menguraikan cara penyelesaian sengketa yang menggunakan arbitrase online sebagai ODR. Kedua, menguraikan dan mengkaji arbitrase online dalam penyelesaian sengketa bisnis e-commerce sudah sesuai dengan cara penyelesaian sengketa di Indonesia.

\section{Metode Penelitian}

Penelitian mengenai penyelesaian sengketa $e$-commerce dengan menggunakan arbitrase online merupakan jenis penelitian hukum normatif, ${ }^{6}$ yaitu penelitian yang mengacu kepada peraturan perundang-undangan yang berlaku baik di Indonesia maupun konvensi internasional. Penelitian ini dapat pula disebut sebagai penelitian doktrinal $^{7}$ karena peneliti berusaha menemukan prinsip-prinsip yang berkaitan dengan permasalahan yang diteliti.

\footnotetext{
${ }^{5}$ Sutan Remy Sjahdeini, Op.Cit., hlm. 25.

${ }^{6}$ Soerjono Soekanto dan Sri Mamudji, Penelitian Hukum Normatif, Rajawali Presss, Jakarta, 2004, hlm. 13.

${ }^{7}$ Bambang Sunggono, Metode Penelitian Hukum, Rajawali Press, Jakarta, 2007, hlm. 83.
} 
Sifat penelitian ini adalah deskriftif analitis, karena dari penelitian ini diharapkan akan diperoleh gambaran secara menyeluruh (holistik) mendalam dan sistematis mengenai penerapan arbitrase online dalam penyelesaian sengketa transaksi e-commerce.

Untuk menjawab permasalahan yang dilakukan pengumpulan bahan hukum dilakukan melalui studi dokumen (studi kepustakaan) meliputi bahan hukum primer, bahan hukum sekunder dan bahan hukum tersier, yakni dengan cara melakukan inventarisasi dan diidentifikasi terhadap sejumlah peraturan perundang-undangan, konvensi-konvensi internasional, dokumen hukum, catatan hukum, hasil-hasil karya ilmiah dan bahan bacaan/literatur yang berasal dari ilmu pengetahuan hukum dalam bentuk buku, artikel, jurnal dan hasil penelitian yang ada kaitannya dengan penelitian ini.

Pengolahan bahan hukum pada umumnya dilakukan dengan cara pemeriksaan bahan hukum (editing), penandaan bahan hukum (coding), rekonstruksi bahan hukum (reconstruction) dan sistematika bahan hukum (systematizing). Analisis yang digunakan dalam penelitian ini adalah metode kualitatif. Teknik analisis dilakukan secara interpretasi, yaitu bahan hukum diinterpretasikan dan dijabarkan dengan mendasarkan pada suatu norma-norma dan teori-teori ilmu hukum yang berlaku, sehingga pengambilan keputusan yang menyimpang seminimal mungkin dapat dihindari. Penarik kesimpulan dilakukan dengan mempergunakan metode penalaran secara induktif, yaitu suatu pemikiran secara sistematis dari khusus ke umum, dan deduktif ialah suatu pemikiran secara sistematis dari umum ke khusus.

\section{Hasil dan Pembahasan}

\section{Penerapan Arbitrase Online sebagai ODR dalam Penyelesaian Sengketa}

Dalam penyelesaian sengketa $e$-commerce internasional dimungkinkan untuk diselesaikan-terutama yang meliputi sengketa bernilai kecil-dalam forum yang tepat, yaitu dengan "ODR" yang menjadi cara praktis untuk memberi konsumen remedy yang tepat, murah dan efektif, serta mengurangi penentutan perkara di negara asing. ${ }^{8}$

${ }^{8}$ Karen Alboukrek, "Adapting to A New world of E-Commerce: The Need for Uniform Consumer Protection in the International Electronic Marketplace”, George Washington International Law Review, 2003, hlm. 443. 
ODR mencakup sejumlah proses yang secara umum mempunyai dua ciri: “DR" (yakni dispute resolution) dan "O" (yakni online). Dengan kata lain, menyelesaikan sengketa dan dilakukan secara elektronik. Semua bentuk Alternatif Penyelesaian Sengketa (APS) tradisional terwakili di jaringan. Selain itu, ada proses penyelesaian sengketa baru: automated atau blind-bidding negotiation, ini adalah contoh mekanisme yang hanya ada di online. Gambaran lain adalah non-binding arbitration. Meskipun tidak seluruhnya tidak ada di offline, tetapi ini cenderung menggambarkan seluruh potensi online dan sebagai salah satu mekanisme ODR paling menonjol untuk jenisjenis sengketa tertentu. ${ }^{9}$

Keuntungan bagi pembeli dan pelaku usaha transaksi e-commerce dalam penyelesaian sengketa melalui ODR, antara lain: ${ }^{10}$ Pertama, penghematan waktu dan uang. Sesungguhnya hal ini sudah tampak dalam APS secara "tradisional" dibandingkan dengan penyelesaian melalui jalur litigasi, namun, penyelesaian sengketa secara online akan lebih hemat dibandingkan dengan alternatif penyelesaian sengketa offline. Keuntungan ini karena para pihak tidak perlu membayar biaya yang harus dikeluarkan untuk menghadiri persidangan dan biaya-biaya yang berkaitan dengan hal itu. Kecepatan ODR adalah salah satu keuntungan dasarnya. Pihak-pihak dan pihak netral tidak perlu melakukan perjalanan untuk bertemu; mereka tidak perlu ada di waktu yang sama; jangka waktu antara penyerahan dapat singkat; penyelesaian dapat berdasarkan dokumen saja. ${ }^{11}$

Kedua, biasanya biaya layanan penyelesaian sengketa perdata adalah gabungan dari biaya institusi penyelesaian sengketa, fee dan biaya pihak netral (mediator atau arbiter), dan biaya para pihak, termasuk ongkos hukum. Dalam ODR, beberapa biaya ini tidak ada atau berkurang signifikan. Sebagai contoh tidak ada biaya perjalanan bagi para pihak yang netral dan para pihak yang bersengketa. ${ }^{12}$ Bagi konsumen $e$ commerce yang menghindari biaya besar dalam penyelesaian sengketa, tentu akan lebih mudah menerima penyelesaian sengketa secara elektronik, karena mereka dapat mengerjakannya sendiri dengan fasilitas komputer yang dimiliki. Dalam penyelesaian sengketa kasus B2C digunakan model unilateral user fees yang

${ }^{9}$ Gabrielle Kaufmann-Kohler dan Thomas Schultz, Online Dispute Resolution: Challenges For Contemporary Justice, Kluwer Law Internasional, The Netherlands, 2004, hlm. 11.

${ }^{10}$ Paustinus Siburian, Arbitrase Online: Alternatif Penyelesaian Sengketa Secara Elektronik, Djambatan, Jakarta, 2009, hlm. 110.

${ }^{11}$ Gabrielle Kaufmann-Kohler dan Thomas Schultz, Op.Cit., hlm. 58.

${ }^{12}$ Ibid., hlm. 55. 
menetapkan pihak pelaku usaha yang bersengketa menanggung semua biaya. Hal ini dapat dilakukan dalam bentuk kontribusi tahunan (misalnya biaya keanggotaan atau trust mark) atau dari pembayaran masing-masing kasus. Oleh karena itu, proses penyelesaian sengketa tergantung pada pendanaan oleh salah satu pihak secara eksklusif. ${ }^{13}$

Ketiga, pihak yang menggunakan akses internet lebih yakin dalam menghadapi proses yang akan dijalaninya, sebab mereka dapat dengan mudah mengontrol dan merespons apa yang terjadi dalam proses;

Keempat, jika para pihak enggan melakukan tatap muka, dapat menghindari pertemuan dengan pihak lawannya. Para pihak dapat menghindarkan diri perasaan takut akan diintimidasi dalam proses. Hal ini merupakan persoalan psikologis.

Bentuk cara penyelesaian sengketa dengan cara ODR tidak jauh berbeda dengan APS di dunia nyata, namun sarana yang digunakan berbeda, yakni dengan sarana internet. Bentuk cara penyelesaian sengketa, yaitu: tidak ada pihak ketiga (negosiasi), atau ada yang tidak dapat membuat keputusan pada sengketa tersebut (mediasi), atau yang dapat membuat keputusan (arbitrase).

Di offline, arbitrase dianggap bentuk penyelesaian sengketa alternatif yang utama, karena dari sifat yudisialnya, syarat-syarat dan proses yang dapat digunakan, karakter yang mengikat dan kemudahan pelaksanaan hasilnya, serta bantuan secara hukum yang diwajibkan kepada pengadilan dalam prosedur pelaksanaan putusan arbitrase. ${ }^{14}$

Di online, arbitrase memberikan harapan yang besar untuk penyelesaian sengketa dalam ruang cyber, karena dua alasan. Pertama, karena kurangnya efektivitas mekanisme penyelesaian sengketa yang konsensual dan non-adjudikatif. ${ }^{15}$ Kedua, adjudikasi di pengadilan seringkali tidak operatif karena pertentangan antara teritorialitas pengadilan dan karakter global ruang maya (cyberspace). Ketiga, arbitrase online yang lebih efektif dan tanpa melihat teritorial.

${ }^{13}$ Ibid., hlm. 66.

${ }^{14}$ Ibid., hlm. 27.

${ }^{15}$ Tingkat penyelesaian dari mekanisme penyelesaian sengketa non-adjudikatif tidak menunjukkan bahwa ini efektif; Banyak orang di beberapa situasi tidak mau bernegosiasi atau mediasi dan memerlukan ada orang ketiga yang memutuskan siapa yang benar dan siapa yang salah. Ini adalah salah satu alasan yang membutuhkan pengadilan. Arbitrase adalah bentuk penyelesaian sengketa yang paling tidak alternatif; ini adalah proses penyelesaian sengketa ekstra-yudisial yang hampir sama dengan proses pengadilan; ini adalah penyelesaian sengketa quasi-yudisial. Tetapi ruang siber adalah suatu lingkungan konsensual, yang membutuhkan metode-metode penyelesaian sengketa berbasis persetujuan: bukan pengadilan, tetapi arbitrase. Lihat Ibid., dikutip dari L.J. Gibbons, "Rusticum Judicium? Private "Courts" Enforcing Private Law and Public Rights: Regulating Virtual Arbitration in Cyberspace", Obio Nothern law Review, 2003, hlm. 775-776. 
Perkembangan yang memungkinkan terjadinya perdagangan secara elektronik, telah mengilhami dilakukannya penyelesaian sengketa secara elektronik. Di tengah kegalauan atas sistem hukum yang tidak mudah mengikuti perkembangan dan cepatnya kemajuan, teknologi telah memberikan gagasan tentang penyelesaian sengketa secara online, dalam bentuk arbitrase secara online (e-arbitration). ${ }^{16}$

Arbitrase online menjadi suatu pilihan yang menarik dalam penyelesaian sengketa e-commerce. Karaktristik transaksi di internet merupakan transaksi lintas batas geografis yang menghubungkan antara konsumen dengan pelaku usaha dari berbagai negara yang dapat melahirkan sengketa. Di mana sengketa tersebut nilai nominalnya sebahagian sangat kecil, tetapi membutuhkan penyelesaian yang cepat dan dengan biaya yang tidak terlalu mahal. Berbagai upaya telah dilakukan, di antaranya dengan menyediakan alternatif penyelesaian sengketa secara online, seperti arbitrase online. ${ }^{17}$

\section{Penerapan Arbitrase Online sebagai Salah Satu Cara Penyelesaian Sengketa di Indonesia}

Arbitrase dan alternatif penyelesaian sengketa lainnya secara online tidak jauh berbeda dari arbitrase dan alternatif penyelesaian sengketa secara "tradisional". Perbedaannya hanyalah mengenai cara yang digunakan, yaitu penggunaan saranasarana elektronik dalam penyelenggaraannya. Dalam arbitrase online, pendaftaran perkara, pemilihan arbiter, penyerahan dokumen-dokumen, permusyawarahan para arbiter dalam hal tribunal arbitrase lebih dari seorang arbiter, pembuatan putusan, serta pemberitahuan akan adanya putusan dilakukan secara online. ${ }^{18}$

Permasalahan yang perlu diperhatikan dalam pelaksanaan arbitrase online antara lain dalam hal:19 Pertama, kontrak untuk melakukan arbitrase; Kedua, pemilihan arbiter; Ketiga, pemenuhan prinsip prosedur dasar; Keempat, sifat dan pelaksanaan keputusan yang mengikat dari arbitrase.

${ }^{16}$ Paustinus Siburian, Op.Cit., hlm. 9.

${ }^{17}$ Penyelesaian sengketa secara online mulai dilakukan pada tahun 1995 dengan didirikannya Virtual Magistrate pada Vilanova Center for Law \& Technology. Tujuannya adalah menjadi penyedia jasa penyelesaian sengketa, khusus untuk sengketa-sengketa secara online. Kasus pertama ditangani pada tahun 1996. Dalam kasus tersebut seseorang telah mengajukan gugatan karena telah menerima iklan-iklan yang tidak diminta melalui e-mail yang dikirimkan dengan menggunakan alamat dari America Online (AOL). AOL setuju untuk menanggapi gugatan ini dan Virtual Magistrate yang menangani perkara tadi mengabulkan gugatan penggugat dan memerintahkan kepada AOL untuk tidak lagi mengirim email yang berisi iklan. Lihat http://vmag.org./docs/press/052196.html diakses tanggal 3 Maret 2009.

${ }^{18}$ Paustinus Siburian, Op.Cit., hlm. 37.

${ }^{19}$ Gabrielle Kaufmann-Kohler dan Thomas Schultz, Op.Cit., hlm. 29. 


\section{Kontrak melakukan arbitrase}

Persetujuan melakukan arbitrase dalam suatu kontrak, yang diungkapkan dalam klausul arbitrase, hal ini berarti bahwa kontrak arbitrase itu adalah dasar untuk menyelesaikan sengketa dengan menggunakan arbitrase. Perlunya kontrak arbitrase online menimbulkan berbagai persoalan. Article IV (1) Konvensi New York menentukan: To obtain the recognition and enforcement mentioned in the preceding Article, the party applying for recognition and enforcement shall, at the time of the application supply: a....

$b$. The original agreement referred to in Article II or a duly certified copy thereof. Article II (1) Konvensi New York:

Each Contracting State shall recognize an agreement in writing under which the parties undertake to submit to arbitration all or any differences which have arisen or may arise between them in respect of a defined legal relationship, whether contractual or not, concerning a subject matter capable of settlement by arbitration.

Article II (2) Konvensi New York:

The term "agreement in writing" shall include an arbitral clause in a contract or an arbitration agreement, signed by the parties or contained in an exchange of letters or telegrams.

Article IV mengandung ketidakcocokan dengan Article II Konvensi New York. Dalam Article IV Konvensi New York ayat (1) terdapat dua argumentasi. Pertama, bahwa tanpa adanya tanda tangan maka tidak akan ada sesuatu yang asli. Dengan demikian dapat ditafsirkan mengenai Article IV Konvensi New York ayat (1) bahwa keaslian hanya dapat dipenuhi jika kontrak dibubuhi tanda tangan. Hal tersebut berarti bahwa kontrak dibuat melalui e-mail dan kontrak transaksi e-commerce tidak memenuhi persyaratan keaslian.

Jika hendak diakui maka diperlukan tindakan lebih jauh dengan membubuhkan tanda tangan pada e-mail dan kontrak transaksi e-commerce. Namun, jika perjanjian arbitrase terdapat dalam pertukaran surat dan telegram, tidak ada kewajiban untuk membubuhkan tanda tangan (Article II (2) Konvensi New York). Kekurangan pada adanya tanda tangan membuka permasalahan keaslian (originality) kontrak yang diwajibkan dalam Article IV Konvensi New York yang telah ditentukan. ${ }^{20}$

Jalan keluar yang terbaik dalam kontrak arbitrase online dalam transaksi $e$ commerce adalah bahwa persyaratan tertulis sebagaimana disebutkan dalam Article II dan IV Konvensi New York harus ditafsirkan sesuai dengan UNCITRAL Model Law on Electronic Commerce sehingga kontrak arbitrase online dapat diakui keabsahannya secara hukum.

\footnotetext{
${ }^{20}$ Paustinus Siburian, Op.Cit., hlm. 59.
} 


\section{Pemilihan Arbiter}

Salah satu prinsip yang berkaitan dengan penunjukan arbiter yang tidak memihak. Kapanpun dimungkinkan, para pihak yang bersengketa menunjuk arbiter. Mereka dapat melakukan secara langsung, atau dengan menghubungi otoritas yang ditunjuk - biasanya institusi arbitrase - yang akan membuat penunjukan untuk kepentingan mereka. $^{21}$

Para pihak harus sepakat dalam penunjukan dan arbiter yang ditunjuk harus netral dan independen dari para pihak yang bersengketa. ${ }^{22}$ Selain itu, jika provider penyelesaian sengketa meminta arbiter dipilih dari suatu daftar, maka daftar itu sendiri harus memenuhi sejumlah persyaratan guna memenuhi prinsip tidak memihak atau independen. Daftar itu juga harus ditentukan oleh badan independen (tidak dikendalikan oleh salah satu pihak) dan jumlahnya harus cukup banyak untuk memberikan pilihan yang tepat. ${ }^{23}$

Beberapa provider menerbitkan metode penunjukkan dan juga daftar pihak yang netral (arbiter). Dalam praktiknya pihak yang netral itu ditunjuk oleh para pihak atau provider. Ketika penunjukan dilakukan oleh provider, pihak yang netral dipilih acak tanpa pertimbangan keadaan khusus dari kasusnya atau menurut kriteria yang telah ditentukan sebelumnya ${ }^{24}$ atau dalam cara bebas menentukan di mana provider ODR berusaha menyesuaikan kebutuhan dari kasusnya dan kualifikasi pihak yang netral. ${ }^{25}$

\section{Pemenuhan Prinsip Prosedur Dasar}

Hal lain dari prinsip prosedur ini mewajibkan para pihak yang bersengketa dijamin prosesnya, terutama kesempatan yang layak untuk didengar, yakni hak

${ }^{21}$ A. Redfern dan M. Hunter, Op.Cit., hlm. 195-204. Memberikan inventaris yang lebih terinci dan pembahasan tentang metode-metode yang berbeda dalam menunjuk arbitrase; melalui persetujuan pihak-pihak; melalui perdagangan atau asosiasi lain; melalui institusi profesional; melalui institusi arbitrase; melalui "sistem daftar"; melalui arbiter yang ada; dan melalui pengadilan negara.

${ }^{22}$ Lihat misalnya Bab 11 (3) (a) UNCITRAL Model Law on Commercial Arbitration, "dalam arbitrase dengan tiga arbiter, masing-masing pihak harus menunjuk satu arbiter, dan dua arbiter yang ditunjuk harus menunjuk arbiter ketiga; jika satu pihak tidak menunjuk arbiter dalam tiga puluh hari setelah menerima permintaan dari pihak lain, atau jika dua arbiter tidak menyetujui arbiter ketiga dalam tiga puluh hari penunjukan mereka, maka penunjukan harus dibuat berdasarkan permintaan satu pihak, melalui pengadilan atau otoritas lain yang ditetapkan dalam Bab 6 dan Bab 12 (1) UNCITRAL Model Law on Commercial Arbitration".

${ }^{23}$ Gabrielle Kaufmann-Kohler dan Thomas Schultz, Op.Cit., hlm 31.

${ }^{24}$ Nova Forum mempunyai daftar kriteria penunjukan panelis. Web Assured adalah contoh lain provider yang menggunakan kriteria yang ditetapkan sebelumnya dan diterbitkan pada pemilihan panelis mereka.

${ }^{25}$ Ibid., hlm 46. 
untuk menyajikan kasus, fakta-fakta, bukti, dan pendapat hukum, dan memberi komentar pada kasus lawan. Hak ini mungkin bertentangan dengan kecepatan di mana merupakan salah satu keuntungan ODR dan mengimplikasikan prosedur yang sederhana.

Tingkat due proses yang diperlukan tergantung pada spesifisitas kasus tertentu atau kategori kasus yang ditangani, dan karena itu arbitrase menyesuaikan standar pengujian ulangnya. Arbiter harus bertindak dengan tepat guna dan para pihak harus bekerja sama dalam mencapai keputusan yang cepat. Sebagai contoh, jika para pihak menawarkan bukti yang relevan, maka arbiter harus menerimanya, tetapi dapat membatasi waktu bagi cara kerja arbiter dalam waktu yang singkat. ${ }^{26}$

\section{Sifat yang Mengikat dan Kemampuan Pelaksanaan Keputusan}

Arbitrase merupakan suatu lembaga yang menggantikan cara kerja pengadilan. ${ }^{27}$ Dengan menyetujui arbitrase, para pihak meniadakan yurisdiksi pengadilan. Oleh karena itu, arbiter diberi kekuasaan untuk membuat Putusan yang mempunyai kekuatan mengikat yang sama seperti putusan pengadilan. Namun, bentuk arbitrase online yang paling banyak digunakan adalah arbitrase yang tidak mengikat, yakni arbitrase yang tidak menghasilkan suatu keputusan yang sama kekuatan mengikatnya seperti putusan pengadilan. Arbitrase tidak mengikat, adalah salah satu fenomena dari ODR.

Keberhasilan arbitrase online sangat bervariasi antara arbitrase mengikat para pihak yang bersengketa dan tidak mengikat para pihak yang bersengketa. Putusan yang tidak mengikat lebih sering dibandingkan dengan yang mengikat. Keberhasilan arbitrase online yang tidak mengikat karena tidak dibebani dengan syarat-syarat prosedural yang tegas yang berlaku dalam arbitrase mengikat, yang memungkinkan lebih banyak fleksibilitas. ${ }^{28}$ Selain itu, meskipun hasilnya secara hukum tidak dapat

${ }^{26}$ Ibid., hlm 32-33.

${ }^{27}$ Ibid., "Arbitrase adalah suatu metode, yang tergantung pada persetujuan pihak-pihak pada penyelesaian sengketa melalui individu-individu yang dipilih secara langsung atau tidak langsung oleh pihak-pihak tersebut dan diberikan kewenangan untuk memutuskan sebagai pengganti pengadilan negara, melalui suatu keputusan yang mempunyai pengaruh sama pada suatu keputusan".

${ }^{28}$ Lihat T. Schultz, 'Online Arbitration : Binding or Non-Binding?' [2002] November ODR Monthly www.ombuds.org/center/adr2002-11-schultz.html. Agar efektif, arbitrase harus menyatu dalam beberapa framework yang akan memberi karakternya yang mengikat dan kemampuan pelaksanaan. Cukup jelas, harus ada beberapa framework yang memiliki kekuatan memaksa terhadap pihak-pihak yang memungkinkan pelaksanaan tanpa kerja sama mereka. Dalam kata lain, arbitrase harus “didasarkan” sistem yang memaksa. Dasar pemikiran ini adalah titik awal pembahasan tentang sifat hukum yang direkomendasikan untuk Virtual Magistrate: J. Goldsmith dan L. Lessig, "Grounding the Virtual Magistrate". 
dilaksanakan seperti sebuah putusan, ini dapat dibuat efektif melalui sarana-sarana faktual tertentu dalam dunia online.

Dalam keputusan arbitrase yang mengikat, jika pengakuan dan pelaksanaan putusan dimohonkan di pengadilan, maka menurut Article IV Konvensi New York, pihak yang mengajukan permohonan harus menunjukan kontrak arbitrase yang asli atau salinannya yang sudah disahkan. Pihak yang mengajukan permohonan untuk pengakuan dan pelaksanaan putusan arbitrase harus menyerahkan a duly authenticated original award or duly certified copy thereof (Article IV (1) Konvensi New York).

Jika diperhatikan ketentuan persyaratan putusan arbitrase ini, maka Konvensi New York memberikan persyaratan yang lebih ketat terhadap putusan arbitrase dibandingkan dengan kontrak arbitrase. Untuk kontrak arbitrase cukup ditunjukkan kontrak yang asli (original) atau salinannya yang sudah disahkan, maka terhadap putusan arbitrase diperlukan a duly authenticated original award or duly certified copy thereof. Hal ini berarti bahwa tanda tangan dari arbiter harus diotentikasi oleh pihak ketiga yang dipercaya untuk itu, seperti oleh korps diplomatik atau konsuler. Menyangkut putusan arbitrase yang dibuat secara online tidak memenuhi syarat menurut Konvensi New York. ${ }^{29}$

Guna mengakomodir karakter khusus dari penyelesaian sengketa transaksi $e$ commerce yang menggunakan arbitrase online, maka mekanisme arbitrase online untuk penyelesaian sengketa memerlukan dukungan penegakan oleh negara. ${ }^{30}$

Dalam hukum di Indonesia putusan arbitrase dibedakan menjadi putusan arbitrase nasional dan putusan arbitrase internasinal, yaitu:

\section{Putusan Arbitrase Nasional}

Pelaksanaan (eksekusi) putusan arbitrase nasional dapat dilakukan baik secara sukarela atau secara paksa. Eksekusi putusan arbitrase secara sukarela dimaksudkan sebagai pelaksanaan putusan yang tidak memerlukan campur tangan dari pihak Ketua Pengadilan Negeri, melainkan para pihak yang berkewajiban melaksanakan eksekusi tersebut (melaksanakan sendiri isi putusan arbitrase tersebut). ${ }^{31}$

Eksekusi secara paksa dimaksudkan jika pihak yang berkewajiban melaksanakan kewajibannya berdasarkan isi putusan arbitrase tidak mau melaksanakan

${ }^{29}$ Paustinus Siburian, Op.Cit., hlm. 104.

${ }^{30}$ Yun Zhao, Dispute Resolution in Electronic Commerce, Martinus Nijhoff Publishers, Leiden/Boston, 2005, hlm. 29.

${ }^{31}$ Munir Fuady, Arbitrase Nasional: Alternatif Penyelesaian Sengketa Bisnis, Bandung: PT Citra Aditya Bakti, 2000, hlm. 161. 
kewajibannya itu, maka diperlukan campur tangan Ketua Pengadilan Negeri dan aparatnya untuk memaksakan pelaksanaan eksekusi yang bersangkutan. ${ }^{32}$

Untuk dapat dieksekusi suatu putusan arbitrase, sebelumnya harus dilakukan suatu prosedur hukum yang disebut dengan "Akte Pendaftaran". Akte pendaftaran adalah pencatatan dan penandatanganan pada bagian akhir atau di pinggir dari putusan arbitrase asli atau salinan otentik yang ditandatangani bersama-sama oleh Panitera Pengadilan Negeri dan arbiter atau kuasanya. ${ }^{33}$ Dalam hal inilah yang menjadi kendala dari pelaksanaan eksekusi arbitrase online, baik dalam hal bentuk putusan yang harus tertulis dan maupun keharusan adanya tanda tangan oleh arbiter dan Panitera Pengadilan Negeri dalam akte pendaftaran.

Dalam Undang-Undang Alternatif Penyelesaian Sengketa (UUAPS)APS mengatur bahwa suatu putusan harus dibuat secara tertulis dan ditandatangani oleh arbiter atau majelis arbiter. Dalam Pasal 54 ayat (2) dan (3), yaitu:

(2) Tidak ditandatanganinya putusan arbitrase oleh salah seorang arbiter dengan alasan sakit atau meninggal dunia tidak mempengaruhi kekuatan berlakunya putusan.

(3) Alasan tentang tidak adanya tanda tangan sebagaimana dimaksud dalam ayat (2) harus dicantumkan dalam putusan.

Ketentuan dalam Pasal 54 itu menentukan bahwa diperlukan tanda tangan dari arbiter. Ketentuan tersebut tidak sepenuhnya menandakan bahwa putusan arbitrase harus dibuat secara tertulis. Ketentuan dalam Pasal 59 ayat (1) lebih memperjelas bahwa putusan harus dibuat secara tertulis. Pasal 59 ayat (1) sebagai berikut:

Dalam waktu paling lama 30 (tiga puluh) hari terhitung sejak tanggal putusan diucapkan, lembar asli atau salinan otentik putusan arbitrase diserahkan dan didaftarkan oleh arbiter atau kuasanya kepada Panitera Pengadilan Negeri.

Pasal 59 ayat (2) lebih memperjelas bahwa putusan arbitrase harus tertulis, yaitu:

Penyerahan dan pendaftaran sebagaimana dimaksud dalam ayat (1), dilakukan dengan pencatatan dan penandatanganan pada bagian akhir atau pinggir putusan oleh Panitera Pengadilan Negeri dan arbiter atau kuasanya yang menyerahkan, dan catatan tersebut merupakan akte pendaftaran.

Dengan demikian panitera pengadilan dan arbiter atau kuasanya memberikan tanda tangan pada bagian akhir atau pinggir putusan. Pasal 63 juga menentukan lebih jauh bahwa Perintah Ketua Pengadilan Negeri tertulis pada lembar asli atau salinan otentik putusan arbitrase yang dikeluarkan. Dengan demikian untuk putusan

\footnotetext{
${ }^{32}$ Ibid.

${ }^{33}$ Ibid.
} 
arbitrase nasional putusan harus tertulis, asli, dan ditandatangani oleh arbiter atau majelis arbitrase. Putusan arbitrase secara online dengan demikian tidak memenuhi persyaratan menurut UUAAPS.

Dalam hal penyerahan dan pendaftaran putusan arbitrase dilaksanakan dengan cara melakukan pencatatan dan penandatanganan pada bagian akhir atau pinggir putusan, selanjutnya catatan tersebut menjadi dasar dan merupakan akte pendaftaran. Pencatatan tersebut merupakan satu-satunya dasar bagi pelaksanaan putusan arbitrase oleh pihak yang berkepentingan atas pelaksanaan putusan arbitrase tersebut.

Oleh karena UUAAPS menentukan bahwa jika pencatatan tersebut tidak dilakukan sesuai atau dalam jangka waktu yang ditentukan, maka putusan arbitrase tersebut tidak dapat dilaksanakan. Selain itu UUAAPS juga mewajibkan arbiter atau kuasanya untuk menyerahkan putusan dan lembar asli pengangkatan sebagai arbiter atau salinan otentiknya kepada Panitera Pengadilan Negeri.

Perintah pelaksanaan putusan arbitrase oleh ketua pengadilan negeri, diberikan dalam waktu selambat-lambatnya 30 (tiga puluh) hari setelah permohonan eksekusi didaftarkan kepada panitera pengadilan negeri. Sebagai balancing bagi kepentingan para pihak dalam putusan arbitrase, ketua pengadilan negeri, sebelum memberikan perintah pelaksanaan, diberikan hak untuk memeriksa terlebih dahulu apakah putusan arbitrase tersebut telah diambil dalam suatu proses yang sesuai, di mana: ${ }^{34}$ Pertama, arbiter atau majelis arbitrase yang memeriksa dan memutus perkara telah diangkat oleh para pihak sesuai dengan kehendak mereka; Kedua, perkara yang diserahkan untuk diselesaikan oleh arbiter atau majelis arbitrase tersebut adalah perkara yang menurut hukum memang dapat diselesaikan dengan arbitrase; Ketiga, putusan yang dijatuhkan tersebut tidak bertentangan dengan kesusilaan dan ketertiban umum.

Selain ketiga hal di atas, ketua pengadilan negeri tidak diberikan kewenangan untuk memeriksa alasan atau pertimbangan dari putusan arbitrase. Jika menurut pertimbangan ketua pengadilan negeri, ada satu atau lebih syarat dari ketiga syarat tersebut di atas yang tidak terpenuhi, maka ketua pengadilan negeri dapat menolak permohonan pelaksanaan eksekusi dan terhadap putusan ketua pengadilan negeri tersebut tidak terbuka upaya hukum apapun. ${ }^{35}$

\footnotetext{
${ }^{34}$ Gunawan Widjaja, Alternatif Penyelesaian Sengketa, PT RajaGrafindo Persada, Jakarta, 2001, hlm. 141-142. ${ }^{35}$ Ibid.
} 


\section{Putusan Arbitrase Internasional}

Tempat di mana putusan arbitrase dijatuhkan memiliki peranan yang sangat penting dalam rangka pelaksanaan putusan arbitrase yang dijatuhkan tersebut. Setiap putusan arbitrase yang dijatuhkan di luar suatu negara, di mana putusan arbitrase tersebut dimaksudkan untuk dilaksanakan, dikenal dengan istilah arbitrase internasinal atau arbitrase asing.

Sebelum berlakunya UUAAPS tersebut, Indonesia telah maratifikasi Konvensi tentang Pengakuan dan Pelaksanaan Putusan Arbitrase Asing (Convention on the Recognition and Enforcement of Foreign Arbitral Awards - New York Convention 1958) yang di" undang"kan dalam Keputusan Presiden Republik Indonesia No. 34 Tahun 1981. Keputusan Presiden tersebut, yang meskipun telah disahkan untuk diberlakukan di Indonesia pada 1981, namun pelaksanaannya baru efektif di tahun 1990 dengan dikeluarkannya Peraturan Mahkamah Agung No. 1 Tahun 1990 tentang Tata Cara Pelaksanaan Putusan Arbitrase Asing tanggal 1 Maret 1990. ${ }^{36}$

UUAAPS tidak mengenal istilah putusan arbitrase asing melainkan putusan arbitrase internasional, yang didefinisikan dalam UUAAPS Pasal 1 angka 9, yaitu:

"Putusan yang dijatuhkan oleh suatu lembaga arbitrase atau arbiter perorangan di luar wilayah bukan Republik Indonesia, atau putusan suatu lembaga arbitrase atau arbiter perorangan yang menurut ketentuan hukum Republik Indonesia dianggap sebagai suatu putusan arbitrase internasional".

Definisi yang diberikan tersebut pada pokoknya merupakan pengulangan dari ketentuan yang diatur dalam Peraturan Mahkamah Agung No. 1 Tahun 1990, di mana dikatakan:

“Yang dimaksud dengan Putusan Arbitrase Asing adalah putusan arbitrase yang dijatuhkan oleh suatu Badan Arbitrase ataupun Arbiter perorangan di luar wilayah hukum Republik Indonesia, ataupun putusan suatu Badan Arbitrase ataupun Arbiter perorangan yang menurut ketentuan hukum Republik Indonesia dianggap sebagai suatu putusan Arbitrase Asing, yang berkekuatan hukum tetap sesuai dengan Keppres No. 34 Tahun 1981 Lembaran Negara Tahun 1881 No. 40 tanggal 5 Agustus 1981".

Pada dasarnya arbitrase online internasional menangani sengketa yang terjadi dalam transaksi e-commerce, yang menjadi persoalan bagaimana keabsahan dan pelaksanaan eksekusi keputusan itu dalam hukum di Indonesia. Nampaknya pelaksanaan putusan arbitrase online dalam sengketa konsumen internasional dalam hukum di Indonesia belum bisa diterapkan, karena adanya berbagai kendala hukum.

${ }^{36}$ Ibid., hlm. 156. 
Putusan arbitrase internasional menurut UUAAPS, dalam Pasal 67 ayat (2) (a), yaitu: (2) Penyampaian berkas permohonan pelaksanaan sebagaimana dimaksud dalam ayat (1) harus disertai dengan: a. Lembar asli atau salinan otentik Putusan Arbitrase Internasional, sesuai dengan perihal otentifikasi dokumen asing, dan naskah terjemahan resminya dalam bahasa Indonesia.

Persyaratan yang diberikan oleh UUAAPS lebih longgar dibandingkan dengan yang diberikan oleh Konvensi New York. UUAAPS tidak mempersyaratkan bahwa lembar asli itu diotentikan terlebih dahulu. ${ }^{37}$

Tata cara pendaftaran dan pencatatan putusan arbitrase internasional, sebagai salah satu syarat agar putusan arbitrase internasional dapat dilaksanakan di negara Indonesia diatur dalam Ketentuan Pasal 67, Pasal 68, dan Pasal 69 UUAAPS yang merupakan pembaharuan dan penyempurnaan dari ketentuan serupa yang diatur dalam Peraturan Mahkamah Agung No. 1 Tahun 1990.

Menurut UUAAPS, permohonan pelaksanaan putusan tersebut diserahkan dan didaftarkan oleh arbiter atau kuasanya kepada Panitera Pengadilan Negeri Jakarta Pusat. Penyampaian berkas permohonan pelaksanaan tersebut harus disertai dengan: ${ }^{38}$ Pertama, lembar asli atau salinan otentik Putusan Arbitrase Internasional, sesuai ketentuan perihal otentifikasi dokumen asing, dan naskah terjemah resminya dalam Bahasa Indonesia; Kedua, lembar asli atau salinan otentik kontrak yang menjadi dasar Putusan Arbitrase Internasional sesuai dengan ketentuan perihal otentifikasi dokumen asing, dan naskah terjemahan resminya dalam Bahasa Indonesia; Ketiga, keterangan dari perwakilan diplomatik Republik Indonesia di negara tempat Putusan Arbitrase Internasional tersebut ditetapkan, yang menyatakan bahwa negara pemohon terikat pada perjanjian, baik secara bilateral maupun multilateral dengan negara Republik Indonesia perihal pengakuan dan pelaksanaan Putusan Arbitrase Internasional.

Tidak semua putusan arbitrase internasional dapat dieksekusi di Indonesia, akan tetapi agar putusan tersebut dapat dieksekusi di Indonesia, harus memenuhi syaratsyarat sebagai berikut:

Pertama, Asas reciprositas (asas timbal balik). Putusan arbitrase internasional dijatuhkan oleh arbitrase dari negara yang dengan Indonesia terikat pada perjanjian, baik secara bilateral maupun multilateral. Hai ini diatur dalam Pasal 66 huruf (a) UUAAPS, yaitu:

\footnotetext{
${ }^{37}$ Paustinus Siburian, Loc.Cit.

${ }^{38}$ Gunawan Widjaja, Alternatif ..., Op.Cit., hlm. 159-160.
} 
"Putusan arbitrase internasional dijatuhkan oleh arbiter atau majelis arbitrase di suatu negara yang dengan negara Indonesia terikat pada perjanjian, baik secara bilateral maupun multilateral, mengenai pengakuan dan pelaksanaan Putusan Arbitrase Internasional".

Ketentuan ini mempertegas adanya asas timbal balik yang secara umum dikenal dalam hukum perdata internasional. Asas ini secara langsung menunjuk kepada berlakunya Convention on the Recognition and Enforcement of Foreign Arbitral AwardsNew York Convention 1958 sebagaimana telah disahkan dengan Keputusan Presiden No. 34 Tahun $1981 .^{39}$

Ketentuan tersebut ini merupakan pencerminan dari asas timbal balik antar negara, tidak semua putusan arbitrase asing diakui dan dapat dieksekusi. Putusan arbitrase asing yang dapat diakui dan dieksekusi hanya terbatas pada putusan yang diambil di negara asing yang memiliki ikatan bilateral maupun multilateral dengan Indonesia dan terikat bersama dengan Indonesia dalam suatu konvensi internasional.

Dalam berbagai kasus para pengguna jasa arbitrase online sebagian besar adalah orang-orang yang melakukan transaksi dagang di internet dengan nilai yang tidak begitu besar. Transaksi-transaksi lebih mengarah kepada sektor B2C.

Oleh karena transaksi tersebut seringkali melintasi batas negara, maka untuk memudahkan proses tuntutan atau penyelesaian sengketa dipilih suatu sistem penyelesaian sengketa yang cepat, murah dan tidak dibatasi oleh batas negara, yaitu ODR yang didalamnya terdapat arbitrase online.

Sengketa yang terjadi antara pelaku usaha yang menjual produknya di internet dengan konsumen yang berdomisili di manapun di belahan dunia asalkan terhubung jaringan internet, maka besar kemungkinan konsumen membeli barang dari pelaku usaha yang negara asalnya tidak mempunyai ikatan-ikatan seperti yang disyaratkan oleh Pasal 66 huruf a UUAAPS, akibatnya apabila sengketa tersebut diajukan melalui lembaga arbitrase online yang berasal dari negara pelaku usaha, maka hasil keputusannya tidak akan dapat dieksekusi.

Dalam jaringan internet seseorang atau bahkan suatu negara tidak dapat membatasi atau melarang apabila warganya melakukan transaksi dagang dengan seseorang yang berada di belahan bumi lain. Perkembangan Alternatif Penyelesaian Sengketa secara online belum berkembang mendunia mengingat lembaga ini relatif baru. Namun apabila melihat perkembangan teknologi informasi yang sangat pesat

${ }^{39}$ Ibid., hlm. 157. 
saat ini permintaan untuk ODR ini sangatlah besar. Misalnya putusan provider ODR yang berasal dari Amerika Serikat telah dapat dieksekusi di negara-negara Eropa seperti Perancis, Inggris dan Jerman begitu pula sebaliknya.

Kedua, Termasuk lingkup hukum perdagangan. Putusan arbitrase internasional agar dapat dieksekusi di Indonesia terbatas pada putusan dalam ruang lingkup perdagangan. Penjelasan Pasal 66 huruf b UUAAPS, menjelaskan yang termasuk ruang lingkup hukum perdagangan meliputi: perniagaan, perbankan, keuangan, penanaman modal, industri, dan hak kekayaan intelektual.

Ketiga, Tidak bertentangan dengan ketertiban umum. Putusan arbitrase internasional tersebut tidak boleh bertentangan dengan ketertiban umum dalam sistem hukum di Indonesia. Asas tidak boleh bertentangan dengan kepentingan umum merupakan asas umum yang sudah diakui secara universal dalam hukum internasional. Meskipun diakui secara universal, namun sampai saat ini, secara praktis, para ilmuan hukum di dunia masih belum dapat mencapai konsensus dalam rumusan apa yang dimaksud dengan ketertiban umum tersebut, sehingga dapat mengakibatkan tidak dapat dilaksanakannya suatu putusan arbitrase internasional. Sebagai gambaran umum dapat disampaikan bahwa asas ini merupakan refleksi dari berlakunya dwingendele regels dalam suatu negara yang berdaulat. Hukum Internasional (publik) mengakui adanya kedaulatan penuh (souvereignity) dari suatu negara di mata internasional. Ini berarti secara prinsipil, tidak ada suatu negarapun di dunia ini yang dapat memaksakan berlakunya suatu ketentuan pada negara lain, dengan cara apapun juga, selama dan sepanjang hal tersebut tidak sesuai dengan kaedah-kaedah dan sendi-sendi kehidupan bernegara atau dalam arti kata lain tidak dikehendaki oleh negara lain tersebut.

Keempat, Mendapat eksekuatur dari Ketua Pengadilan Negeri Jakarta Pusat. UUAAPS menentukan bahwa yang berwenang menangani masalah pengakuan dan pelaksanaan Putusan Arbitrase Internasional adalah Pengadilan Negeri Jakarta Pusat (Pasal 65). Putusan Arbitrase Internasional tersebut baru dapat dilaksanakan di Indonesia setelah memperoleh eksekuator dari Ketua Pengadilan Negeri Jakarta Pusat. Namun, apabila putusan Arbitrase Internasional tersebut menyangkut negara Republik Indonesia, baru Mahkamah Agung yang memberikan eksekuator. ${ }^{40}$

Terhadap putusan Ketua Pengadilan Negeri Jakarta Pusat sebagaimana dimaksud dalam Pasal 66 huruf d yang mengakui dan melaksanakan putusan

${ }^{40}$ Erman Rajagukguk, Arbitrase Dalam Putusan Pengadilan, Chandra Pratama, Jakarta, 2000, hlm. 62. 
arbitrase internasional, tidak dapat diajukan banding atau kasasi (Pasal 68 ayat (1)). Namun terhadap putusan Ketua Pengadilan Negeri Jakarta Pusat sebagaimana dimaksud dalam Pasal 66 huruf d yang menolak untuk mengakui dan melaksanakan putusan Arbitrase Internasional, dapat diajukan kasasi (Pasal 68 ayat (2)). Mahkamah Agung mempertimbangkan serta memutuskan setiap pengajuan kasasi sebagaimana dimaksud dalam ayat (2), dalam waktu paling lama 90 (sembilan puluh) hari setelah permohonan kasasi tersebut diterima oleh Mahkamah Agung (Pasal 68 ayat (3)). ${ }^{41}$

Akhirnya, menurut ayat (4), terhadap putusan Mahkamah Agung sebagaimana dimaksud Pasal 66 huruf e, tidak dapat diajukan perlawanan. Pasal 69 ayat (1) menyatakan bahwa setelah Ketua Pengadilan Negeri Jakarta Pusat memberikan perintah eksekusi sebagaimana dimaksud dalam Pasal 64, maka pelaksanaan selanjutnya dilimpahkan kepada Ketua Pengadilan Negeri yang secara relatif berwenang melaksanakannya. Pasal 64 ayat (2) ini menyatakan bahwa sita eksekusi dapat dilakukan atas harta kekayaan serta barang milik termohon eksekusi. Tata cara penyitaan serta pelaksanaan putusan mengikuti tata cara sebagaimana ditentukan dalam hukum acara perdata (Pasal 64 ayat (3)). ${ }^{42}$

Permasalahan dalam putusan arbitrase online, apakah putusan arbitrase online bisa dikategorikan putusan Arbitrase Internasional? Apakah dapat dieksekusi sebagaimana Putusan Arbitrase Internasional? Dalam hal ini peraturan perundangundangan di Indonesia belum mengaturnya.

Dalam hal tersebut seyogianya Indonesia harus mengubah beberapa peraturan untuk dapat menerapkan putusan arbitrase online di Indonesia, sehingga dapat memberikan kepastian bagi pelaku usaha dan konsumen yang bertransaksi dengan menggunakan e-commerce internasional.

\section{Penutup}

Cara penyelesaian sengketa dengan jalur litigasi dan non litigasi konvensional yang masih berdasarkan dunia nyata, kesulitan menjadi solusi terbaik sebagai sarana penyelesaian sengkata. Perkembangan dari penyelesaian sengketa e-commerce internasional yang terbaru, yaitu dengan arbitrase online sebagai salah satu cara penyelesaian sengketa dengan menggunakan $O D R$, dianggap oleh para pelaku bisnis

\footnotetext{
${ }^{41}$ Ibid.

${ }^{42}$ Ibid., hlm. 63.
} 
e-commerce, sebagai solusi terbaik dalam menyelesaikan masalah sengketa di dunia maya. Namun Arbitrase Online dalam pelaksanaannya menghadapi kendala yuridis, dalam hal: (1) kontrak untuk melakukan arbitrase; (2) pemilihan arbiter; (3) pemenuhan prinsip prosedur dasar; (4) sifat dan pelaksanaan keputusan yang mengikat dari arbitrase. Untuk lebih mengembangkan bisnis transaksi e-commerce dan kepercayaan pelaku bisnis perlunya lebih dikembangkan sistem penyelesaian sengketa dengan memanfaatkan Arbitrase Online dan menghilangkan kendala hukum dalam keabsahan proses, dan pelaksanaan putusan Arbitrase Online.

\section{Daftar Pustaka}

Alboukrek, Karen, "Adapting to A New world of E-Commerce: The Need for Uniform Consumer Protection in the International Electronic Marketplace", George Washington International Law Review, 2003.

Darus Badrulzaman, Mariam, et.al., Kompilasi Hukum Perikatan, PT. Citra Aditya Bakti, Bandung, 2003.

Fuady, Munir, Arbitrase Nasional: Alternatif Penyelesaian Sengketa Bisnis, Bandung: PT Citra Aditya Bakti, 2000.

Gibbons, L.J., "Rusticum Judicium? Private "Courts" Enforcing Private Law and Public Rights: Regulating Virtual Arbitration in Cyberspace", Ohio Nothern law Review, 2003.

Kartaatmadja, Komar, Beberapa Masalah Dalam Penerapan ADR Di Indonesia, Dalam Prospek dan Pelaksanaan Arbitrase di Indonesia, PT Citra Aditya Bakti, Bandung, 2001.

Kaufmann-Kohler, Gabrielle dan Thomas Schultz, Online Dispute Resolution: Challenges For Contemporary Justice, Kluwer Law Internasional, The Netherlands, 2004.

Rajagukguk, Erman, Arbitrase Dalam Putusan Pengadilan, Chandra Pratama, Jakarta, 2000.

Schultz, T.,'Online Arbitration: Binding or Non-Binding?' [2002] November ODR Monthly www.ombuds.org/center/adr2002-11-schultz.html. diakses 22 Juli 2006.

Siburian, Paustinus, Arbitrase Online: Alternatif Penyelesaian Sengketa Secara Elektronik, Djambatan, Jakarta, 2009.

Soekanto, Soerjono dan Sri Mamudji, Penelitian Hukum Normatif, Rajawali Presss, Jakarta, 2004.

Soekanto, Soeryono, Mengenai Antropologi Hukum, Alumni, Bandung, 2002.

Sunggono, Bambang, Metode Penelitian Hukum, Rajawali Press, Jakarta, 2007.

Remy Sjahdeini, Sutan, "E-Commerce Tinjauan dari Perspektif Hukum". Jurnal Hukum Bisnis, diterbitkan oleh Yayasan Pengembangan Hukum Bisnis. Vol. 12, 2001, Jakarta. 
Widjaja, Gunawan, AlternatifPenyelesaian Sengketa, PT RajaGrafindo Persada, Jakarta, 2001.

Zhao, Yun, Dispute Resolution in Electronic Commerce, Martinus Nijhoff Publishers, Leiden/Boston, 2005. 